INTERNATIONAL JOURNAL OF SYSTEMATIC BACTERIOLOGY

Vol. 17, No. 4

October 1967

pp. $361-366$

Copyright 1967, Iowa State University Press

\title{
ON THE TAXONOMIC POSITION OF THE GENUS MICROELLOBOSPORIA CROSS, LECHEVALIER AND LECHEVALIER 1963
}

H. Prauser, Liselotte Müller and Rosmarie Falta

Institut für Mikrobiologie und experimentelle Therapie Jena, DDR

ABSTRACT. The genera Microellobosporia Cross et al. and Streptomyces Waksman and Henrici are alike inseveralfeatures: identical cell-wall composition, similar cell-wall antigens, susceptibility to the same polyvalent actinophages, and similar appearance of agar cultures. In all these properties there is no or little similarity to Streptosporangium Couch and Actinoplanes Couch. Because there are, in addition, nofundamental differences in sporeformation in the sporangia of the Actinoplanaceae and in the sporogenichyphae of the Streptomycetaceae, we propose the transference of the genus Microellobosporia from the Actinoplanaceae to the family Streptomycetaceae.

The three species of two recently described genera of the Actinomycetales, Macrospora violacea Tsyganov, Zhukova and Timofeeva (May 1963), Microellobosporia cinerea and M. flavea Cross, Lechevalier and Lechevalier (June 1963) proved to represent one genus only (Becker, Lechevalier and Lechevalier 1965; Zhukova and Tsyganov 1966). Since Macrospora is a later homonym of a validly published fungal genus the correct name is Microellobosporia (Lechevalier and Holbert 1965).

With regard to the production of sporangia Microellobosporia was placed in the Actinoplanaceae by both groups of authors. Prauser (1967), however, arranged the genus in the Streptomycetaceae. The reasons will be discussed here. Two Microellobosporia strains were studied, M. flavea IMRU 3857 (from Dr. H. A. Lechevalier) and our isolate IMET 188, which resembles M. violacea. 
Morphology. Beginning in 1963 the major work on the spore-bearing processes in the Actinoplanaceae, i. e. in Microellobosporia, Streptosporangium, Actinoplanes, and Spirillospora, was done by H. A. Lechevalier and collaborators by means of electron microscopic observations of ultrathin sections. Recently the data previously presented in two papers and a dissertation were completed, summed up and .again interpreted (Lechevalier et al. 1966). Here only the fundamental facts and observations may be quoted and compared with those concerning the streptomycetes.

In the Actinoplanaceae studied thus far the hyphal wall at the tips of sporangia-bearing hyphae consists of two layers. The outer one becomes "baggy" and gives rise to the sporangial wall. The hypha, now covered only with the inner layer which is thought to be the cell wall sensu stricto, is growing into the enlarging sporangium. Numerous spores are formed simultaneously by annular ingrowth of the wall of this hypha. Obviously this mode of intrasporangial spore formation is only superficially similar to that known from fungi and algae. There the spores are formed by segregation of the sporangium content and de novo formation of spore walls. With Actinoplanaceae the spore-bearing process is much more a veiled production of conidia.

In sporogenic hyphae of a streptomycete with smooth spores Glauert and Hopwood (1961) and Hopwood and Glauert (1961) observed two cell-wall layers and a fibrous sheath. The walls of the spore poles are formed by annular ingrowth of the inner component only. So the outer layer and the sheath are not implicated in the basic spore-bearing process. They passively break up at the level of the interspore pads when the spores individualize, and can be seen sometimes as "cuffs" on the conidiospores. Similar conditions were found to apply for a streptomycete with spiny conidia (Rancourt and Lechevalier 1964).

Thus the outer layer of the hyphal wall in Streptomyces and the sporangial walls in Actinoplanaceae including Microellobosporia may be interpreted as analogous: they cover the spore-bearing parts. Moreover, they also may be understood to be homologous, because they originate from similarly situated components of the cell walls. In Streptomyces merely the outer layer does not separate from the inner one, as occurs with the Actinoplanaceae, but becomes a more or less adherent part of the spore.

Cultures of Microellobosporia resemble those of Streptomyces very closely. 
Cell-wall composition. Cummins and Harris (1956) found in pure cell-wall preparations of two streptomycetes hexosamine, alanine, glutamic acid, glycine and LL-2,6-diaminopimelic acid. Yamaguchi (1965) and Becker et al. established the same cell-wall type in all those genera, which, according to the definition of the Streptomycetaceae (Lechevalier and Lechevalier 1965), a re to be placed in this family, i. e. in Streptomyces, Streptoverticillium, Chainia, Actinopycnidium, Actinos porangium, and likewise in Microellobosporia. IMET 188 possesses this cell-wall composition also (Prauser 1966). Within the Actinomycetales this type further occurs only in some nocardioform* organisms (Prauser 1966).

Serology. Cell-wall antibodies against Streptomyces griseus ATCC 10971 were tested with polysaccharide extracts (Boivin and Mesrobeanu 1937) of 48 strains from 15 genera of the Actinomycetales by means of the agar-gel diffusion technique. With the exception of homologous reactions the antibodies precipitate only with polysaccharideextracts of the two Microellobosporia strains. While $\underline{M}$. flavea antibodies only gave the homologous reaction, those of IMET 188 were veryweakly active against polysaccharide extracts of Nocardia corallina (syn. Mycobacterium agreste) ATCC 4273, N. opaca (syn. M. crystallophagum) ATCC 4276, one of the seven Streptosporangium strains and Thermopolyspora rectivirgula. From the clear results obtained with S. griseus antibodies a certain similarity of Streptomyces and Microellobosporia antigens may be concluded.

Phage susceptibility. From composted soils 36 phages were isolated. Each of these was effective against one or more strains of 9 genera of Actinomycetales. All together 80 strains of 20 genera of Actinomycetales were tested. Five of the phages attacked as many as 24 of 26 Streptomyces strains, Actinomyces biverticillatus N 11189 (from Dr. G.F. Gause), Chainia poonensis RIA 563, Actinopycnidium caeruleum RIA 729, Actinosporangium violaceum RIA 655, Microellobosporia flavea IMRU 3857, and IMET 188, but never strains of other families including Streptosporangium, Actinoplanes, and Spirillospora. The two Microellobosporia strains were susceptible only to such phages that

* "Nocardioform" organisms, quite independently of their taxonomic position, are defined as producing a true substratum mycelium, which later breaks up into short segments. 
in addition were exclusively virulent for strains of genera of the Streptomycetaceae. Vice versa Bradley et al. (1961) did not find Streptomyces strains sensitive to an Actinoplanes phage. Evidently, the Streptomycetaceae and the Actinoplanaceae studied so far differ in their sensitivity to polyvalent actinophages. Microellobosporia behaves like the genera of Streptomycetaceae.

No phages were found which attacked both Streptomyces and Nocardia strains as it was reported by Bradley and Anderson (1958) and Bradley et al. though Nocardia asteroides ATCC 3308, Nocardia farcinica PSA 162, N. pelletieri RIA

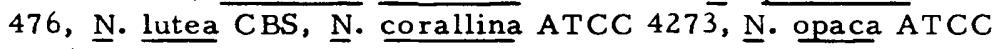
4276 , some unidentified nocardias, some yellow nocardioform strains (Prauser 1967) including $N$. turbata ( $\varnothing$ rskov's motile nocardia No. 27), Promicromonospora citrea RIA 562 were tested.

DNA. Tsyganov et al. (1966) reported for three strains of Microellobosporia cinerea, $\underline{M}$. flavea and $\underline{M}$. violacea the base compositions of their DNA's as 67.6 to $68.4 \% \mathrm{GC}$. IMET 188 was proved to contain 67.4\% (Prauser 1966). In consideration of all other facts this indicates that all investigated Microellobosporia strains are closely related. But the ascertained GC-ratios do not permit conclusions as to the taxonomic inter relationships between Microellobosporia on the one hand and the Streptomycetaceae or Actinoplanaceae on the other, because the reported data on these taxa are rather similar (67-74\% GC, and 68.5-73. 9\% GC). The GC-ratios of Microellobosporia are relatively low. This fact could be interpreted to indicate a somewhat isolated position compared with the other genera with unbreaking substratum mycelium.

Remark. The strain 9-41 with meso-DAP and Microellobosporia-like sporangia which contain motile spores (Higgins et al. 1967) in our opinion would not belong to Microellobosporia.

\section{Culture collections cited}

$\begin{array}{ll}\text { ATCC } & \text { American Type Culture Collection } \\ \text { CBS } & \text { Centraalbureau voor Schimmelcultures, Baarn } \\ \text { IMET } & \text { Institut für Mikrobiologie und experimentelle } \\ & \text { Therapie, Jena } \\ \text { IMRU } & \text { Institute of Microbiology, Rutgers University } \\ \text { PSA } & \text { Progetto Sistematica Actinomiceti, Milan } \\ \text { RIA } & \text { USSR Research Institute for Antibiotics, Moscow }\end{array}$




\section{Literature Cited}

Becker, B., M. P. Lechevalier and H. A. Lechevalier. 1965. Chemical composition of cell-wall preparations from strains of various form-genera of aerobic actinomycetes. Appl. Microbiol. 13:236-243.

Boivin, A. et L. Mes robeanu. 1937. Compt. rend. Soc. Biol. 125:273, quoted from Seeliger, H. P. R. 1958. Mykologis che Se rodiagnostik. J.A. Barth-Verlag, Leipzig.

Bradley, S. G. and D. L. Anderson. 1958. Taxonomic implication of actinophage host-range. Science 128:413-414. and L. A. Jones. 1961. Phylogeny of actino-

mycetes as revealed by susceptibility to actinophage. Developm. industr. Microbiol. 2:223-237.

Cross, T., Mary P. Lechevalier and H. Lechevalier. 1963. A new genus of the Actinomycetales: Microellobosporia gen. nov. J. gen. Microbiol. 31:421-429.

Cummins, C.S. and H. Harris. 1956. A comparison of cell-wall composition in Nocardia, Actinomyces, Mycobacterium and Propionibacterium. J. gen. Microbiol. $15: \mathrm{IX}-\mathrm{X}$.

Glauert, A.M. and D. A. Hopwood. 1961. The fine structure of Streptomyces violaceoruber ( . coelicolor). III. The walls of the mycelium and spores. J. Biophys. Biochem. Cytol. 10:505-516.

Higgins, H. L. , Mary P. Lechevalier and H. A. Lechevalier. 1967. Flagellated actinomycetes. J. Bact. 93:1446-1451.

Hopwood, D. A. and A. M. Glauert. 1961. Electron microscope observations on the surface structures of Streptomyces violaceoruber. J. gen. Microbiol. 26:325-330.

Lechevalier, H. and Pauline E. Holbert. 1965. Electron microscopic observation of the sporangial structure of a strain of Actinoplanes. J. Bact. 89:217-222. and - 1966. Electron microscopic observation of the sporangial structure of strains of Actinoplanaceae. J. Bact. 92:1228-1235. et Mary P. Lechevalier. 1965. Classification des actinomycètes aérobies basée sur leur morphologie et leur composition chimique. Ann. Inst. Pasteur 108:662673.

Prauser, H. 1966. New and rare actinomycetes and their DNA base composition. Spisy přirodov̌ecké Fak. Univ. Brné. 475:268-270.

- 1967. DA_freie, gelbe Actinomyceten mit Tendenz sur Beweglichkeit. Ztschr. Allg. Mikrobiol. 7:81-83. 
Rancourt, Martha W. and H. A. Lechevalier. 1964. Electron microscopic study of the formation of spiny conidia in species of Streptomyces. Canad. J. Microbiol. 10: $311-316$.

Tsyganov, V.A., R. A. Zhukova and K. A. Timofeeva. 1963. A new genus of actinomycetes Macrospora gen. nov. Materials of the 3 rd scientific symposium of the Institute of antibiotics of Leningrad. pp. 90-93.

, V.P. Namestnikova and N. V. Krassikova. 1966. DNA composition in various genera of the Actinomycetales. Mikrobiologiya 35:92-95.

Yamaguchi, T. 1965. Comparis on of the cell-wall composition of morphologically distinct actinomycetes. J. Bact. 89:444-453.

Zhukova, R. A. and V.A. Tsyganov. 1966. Comparative study on actinomycetes of the genera Macrospora and Microellobosporia. Mikrobiologiya 35:833-840. 